\title{
PRAKTEK PROSTITUSI TERSELUBUNG DI KOTA BIMA
}

\author{
Oleh: \\ Adnan, Juhriati dan Syamsuddin \\ adnanshmh@gmail.com, juhriyati@gmail.com,dan \\ syamsuddinbima59@gmail.com \\ Dosen STIH Muhammadiyah Bima
}

\begin{abstract}
:
This paper is summary of the result of research conducted in Kota Bima. It was tried to open the prostitution mask which is done by the students. Besides, the research is a way to search the prostitution motive and how to solve it. The type of this research is the empiric and sociological law, meanwhile, the data is collected by field observation and directly interview. The data of research was analyzed by description method, to describe the data, it need more explanation to solve the prostitution. The result of this research show, there are two main factors why the students do prostitution; firstly internal factor which are consist of low of moral standardization and low of iman quality (Believe to God), life style, psychological burden (traumatic and disappointed). While the external factor is influence by environment (friends), lack of parents, social, or government watching. However, the dominant factor is demand of students life - style who wants life luxury and expensive. Finally, the students can do the prostitution because lack of parent, social (owner the building house, hotel or homestay) and government roles.
\end{abstract}

Keywords: Prostitution, Mask, Kota Bima.

\section{Latar Belakang}

Pelacuran atau prostitusi adalah salah satu penyakit masyarakat/ummat yang terjadi dimana-mana di seantero dunia apakah di barat atau di timur dilakukan oleh seorang wanita dengan seorang laki atau dengan beberapa orang laki dalam bentuk penyerahan diri untuk pemuasan seksual bagi para pihak yang berhubungan dengannya dan dari perbuatan tersebut yang bersangkutan mendapat imbalan.

Prostitusi dapat diartikan salah satu tingkah laku yang melanggar norma kesusilaan, norma hukum, maupun norma Agama terutama agama Islam. bahwa dengan relasi seksual ini kedua belah 
pihak menghayati bentuk kenikmatan dan puncak kepuasan seksual atau organisme, jika dilakukan oleh hubungan yang normal sifatnya ${ }^{1}$.

Selain itu juga bahwa pemenuhan seksual diluar lembaga perkawinan dianggap sebagai tindakan yang menyimpang dari nilai, aturan dan agama yang berlaku di masyarakat. Penyimpangan ini akan mendapat sanksi sosial berupa gunjingan dan celaan yang dilakukan oleh masyarakat serta tidak menutup kemungkinan dikucilkan dari kehidupan masyarakat. Penyimpangan dari norma-norma perkawinan yang wajar seperti prostitusi dan perzinahan tetap ada, ditambah lagi pelanggaran seks atau penyimpangan dari pada hubungan seks yang tidak wajar seperti homo-sexualitas, sex-maniax (sadisme) tetap merupakan penyakit-penyakit masyarakat yang mewarai kehidupan masyarakat ${ }^{2}$.

Selama ini prostitusi/pelacuran pelakunya hanya sebatas orang-orang biasa atau para janda yang telah dicerai oleh suaminya, perempuan yang ditinggalkan oleh pacarnya dan sebagainya, namum sekarang prostitusi sudah menjalar sampai kepada kalangan terdidik yaitu pelajar dan mahasiswa. Hal menjadi keprihatinan kita semua terhadap penyakit sosial ini. Prostitusi dikalangan pelajar dan mahasiswa di Kota Bima menjadi fenomena yang perlu dikaji keberadaannya dari berbagai aspek, sebab Kota Bima adalah merupakan kota transit untuk Indonesia Timur yang siklus perjalanan lalu lintas manusia yang begitu sibuk, sehingga akan berdampak pada daerah itu sendiri, termasuk salah satu problema yang sangat mendasar adalah adanya sejumlah pelajar dan mahasiwa yang memiliki profesi sebagai pelacur.

Kondisi ini sangat memprihatinkan, karena pada hakekatnya tidak ada manusia normal yang ingin bercita-cita menjadi pelacur. Terasa akan lebih mencengangkan kita, jika kemudian diketahui bahwa wanita dari kalangan yang berstatus pelajar dan mahasiwa yang melakukan prostitusi. Padahal, asumsi masyarakat bahwa pelajar dan mahasiswa adalah merupakan salah satu generasi terbaik yang akan melanjutkan perjuangan bangsa dan negara karena dipundak mereka bangsa ini akan diwariskan.

Aktifitas prostitusi merupakan ancaman bagi kehidupan masyarakat, sebab aktifitas prostitusi di anggap sebagai perusak generasi muda yang menjadi harapan bangsa ini, akibatnya dianggap sebagai salah satu sumber penyakit dalam masyarakat. Maraknya perilaku prostitusi terselubung belakangan ini terutama dilakukan oleh kalangan pelajar dan mahasiswa dengan berbagai motif dan tujuan tentunya tidak boleh dibiarkan belangsung begitu saja, melainkan harus ada upaya dan langkah dalam mengatasinya agar tidak terus

${ }^{1}$ Kartini kartono, Patologi Sosial Jilid I, Edisi Revisi,(Jakarta : CV Rajawali) hlm 14

${ }^{2}$ Sudjono D, Pathologi Sosaial (bandung : Peneribit alumin) hlm 22-25 
bertambah meningkat. Selama ini model pemberantasan praktik prostitusi sudah banyak dilakukan, namun demikian belum dapat menghilangkan sama sekali praktik prostitusi. Atas dasar itulah penelitian yang hendak dilakukan ini bertujuan untuk mengetahui motif dan tujuan dari pelaku prostitusi (pelajar dan mahasiswa) dalam segala aspek, sehingga dengan demikian kedepannya praktik prostitusi ini dapat di atasi.

\section{Prostitusi Dari Aspek KUHP}

Di dalam Kitab Undang-Undang Hukum Pidana (KUHP), Buku II mengatur tentang kejahatan. Dalam Buku II KUHP ini berisi rumusan atas perbuatan yang dilarang dan diperintahkan atau yang harus dilakukan, yang dikategorikan sebagai kejahatan. Bertentangan dengan norma-norma menurut kebudayaan atau kadilan yang ditentukan Tuhan atau membahayakan kepentingan hukum³.

Prostitusi dalam hukum Agama Islam merupakan sebagai kejahatan yang harus dihukum apabila telah memenuhi syarat dan termasuk dosa besar, walaupun di dalam hukum positif saai ini pelaku prostitusi tidak bisa dikenakan sanksi pidana karena tidak ada rumusan delik, namun harus diakui bahwa prostitusi merupakan perilaku yang bertentangan dengan norma kesusilaan. Sebab masalah kesusilaan merupakan masalah yang berkaitan dengan nilai-nilai yang hidup.

Kesusilaan hendaknya tidak dibatasi pada pengertian kesusilaan pada bidang seksual, tetapi juga meliputi hal-hal yang termasuk dalam penguasaan norma-norma kepatutan bertingkah laku dalam pergaulan maysarakat. Senada hal tersebut di atas, kejahatan seks serta kejahatan yang menyangkut seks (sex related crims) yang dirumuskan dalam hukum pidana sebagai delik susila senantiasa harus dipahami secara kontekstual dalam hubungannya dengan perkembangan budaya dan perubahan-perubahan dalam struktur sosial, termasuk di dalamnya kekuasaan pria dan perempuan ${ }^{4}$

Masalah prostitusi/pelacur tidak dijelaskan secara rinci dalam hukum positif sebagaimana halnya kejahatan-kejahatan lainnya, sehingga terjadi kesulitan bagi para penegak hukum untuk menjerat pelaku prostitusi pada ranah hukum formal, sehingga masalah prostitusi adalah pengecualian dari asas legalitas. Asas legalitas (principle of legality) asas yang menentukan bahwa tidak ada perbuatan yang dilarang dan diancam dengan pidana jika tidak ditentukan terlebih dahulu dalam perudang-undangan. ${ }^{5}$

\footnotetext{
3 Bambang Poernomo, 1996. Penelitian Hukum Dalam Praktek(Jakarta : Sinar Grafika,) hlm 65

${ }^{5}$ Menurut Niken Savitri (2008: 70), hukum pidana dikenal sebagai pedang yang bermata dua, disatu pihak ia bertujuan, melindungi setiap individu dari segala
} 
Di dalam KUHP terdapat beberapa pasal yang mengatur tentang perbuatan cabul tersebut antara lain pasal 296 yang berbunyi: "Barang siapa dengan sengaja menghubungkan atau memudahkan perbuatan cabul oleh orang lain, dan menjadikannya sebagai mata pencahrian atau kebiasaan, diancam dengan pidana penjara paling lama 1 (satu) tahun 4 (empat) bulan atau denda paling banyak seribu rupiah". Pasal ini, tidak secara tegas menyebut pelacur, yang jelas disebutkan dalam pasal 296 adalah yang menghubungkan atau yang lazim disebut dengan dengan germo. Germo disini bisa diperankan oleh seorang perempuan atau seorang laki-laki, yang semata-mata pekerjaan ini dijadikannya sebuah mata pencahrian.

Pasal ini untuk memberantas orang orang yang mengadakan rumah bordil atau tempat-tempat pelacuran. Supaya dapat dihukum berdasarkan pasal ini, harus dibuktikan bahwa perbuatan itu menjadi "pencaharian" (dengan pembayaran) atau "kebiasaannya" (lebih dari satu kali) ${ }^{6}$.

Penyediaan pekerja seks komersial atau pelacur itu sendiri pada dasarnya melanggar kesusilaan. Karena itu, pemilik gubuk atau bar dilarang menyediakan tempat pekerja seks komersial. Jadi, ketentuan KUHP hanya dapat digunakan untuk menjerat penyedia tempat. Namun demikian, ada yang perlu dicermati di sini adalah bahwa arti prostitusi adalah pemanfaatan seseorang dalam aktifitas seks untuk suatu imbalan.

Dalam Kitab Undang-Undang Hukum Pidana (KUHP) tidak ada satupun pasal yang mengatur secara khusus tentang pelacuran atau wanita pelacur, padahal di dalam hukum pidana terdapat asas legalitas yang termuat dalam Pasal 1 ayat (1) KUHP, yang menyebutkan "Tiada suatu perbuatan dapat dipidana kecuali atas aturan pidana dalam perundang-undangan yang telah ada sebelum perbuatan itu dilakukan."

Hal ini berarti segala perbuatan yang belum diatur di dalam undang undang tidak dapat dijatuhi sanksi pidana. Jadi, belum tentu semua perbuatan melawan hukum atau merugikan masyarakat diberi sanksi pidana. Namun, mengartikan pelacuran tidak dijadikan larangan dalam hukum pidana, janganlah diartikan bahwa pelacuran itu tidak dianggap merugikan masyarakat. Oleh karena itu, perlu dicari rumusan

jenis kejahatan yang melukai kepentingan hukumnya, baik yang berkaitan dengan tubuh, nyawa maupun harta benda. Di lain pihak, hukum pidana dalam melakukan perlindungan atas individu tersebut, ternyata juga harus memberikan individu (dalam hal ini individu yang disangka atau diduga dan diputuskan bersalah melakukan pelanggaran atau kejahatan). Dengan demikian terhadap masalah prostitusi ini di dalam KUHP tidak memberikan suatu kepastian. Pada hal sebuah negara hukum itu harus mempunyai kepastian hukum.

${ }^{6}$ R. Soesilo, 1974. Pokok-pokok Hukum Pidana, Peraturan Umum dan Delik-Delik Khusus, Cet. 1 (Bogor : Politea) hlm 32 
hukum atau peraturan yang tepat menindak aktivitas pelacuran, yang selama ini dalam praktik dapat dilaksanakan oleh penegak hukum ${ }^{7}$.

Pasal 297 KUHP, bahwa "perdangan wanita dan perdagangan laki-laki yang belum cukup umur, diancam dengan pidana penjara paling lama enam tahun". Perdagangan wanita bertujuan untuk menyerahkan wanita ke dalam lokalisasi pelacuran tidak mengenai wanita pelacur, tetapi wanita yang sudah menjadi pelacur pun dapat juga menjadi obyek perbuatan perdagangan wanita.

Sedangkan pasal 506 KUHP menyebutkan "barang siapa menarik keuntungan dari perbuatan cabul dari seorang wanita dan dijadikan sebagai mata pencahrian, diancam dengan kurungan paling lama 1 (satu) tahun". Orang yang menarik keuntungan dari perbuatan tersebut dan menjadikannya sebagai mata pencahrian disebut mucikari. Berdasarkan ketentuan diatas, jika dilihat dari ketiga pasal tersebut yang berhubungan dengan kegiatan pelacuran, ternyata pelacurnya sendiri secara tegas tidak diatur atau tidak diancam oleh hukum pidana.

Unsur-unsur dalam Pasal 506 KUHP ini sebagai berikut:

a. Mucikari adalah orang yang mengambil keuntungan dari pelacuran perempuan.

b. Keuntungan adalah segala hal yang dapat dinilai dengan uang. Pasal ini melarang aktivitas perantara yang secara sengaja mengorganisasikan dan menyediakan fasilitas-fasilitas bagi kegiatan seksual, seperti germo, atau mucikari, mami, pemilik usaha, wanita panggilan ${ }^{8}$.

\section{Prostitusi Dari Aspek Kriminologi}

Memberikan rumusan tentang kejahatan adalah perbuatan yang sangat anti sosial yang memperoleh tentangan dengan sadar dari negara berupa pemberian penderitaan (hukuman atau tindakan), singkatnya Prostitusi adalah merupakan salah satu bentuk kejahatan yang melanggar norma kesusilaan ${ }^{9}$.

Prostitusi merupakan "The offering of sexual relations for monetary or other gain" (penawaran hubungan seksual untuk memperoleh uang atau keuntungan lainnya). Jadi prostitusi adalah seks untuk pencaharian, terkandung beberapa tujuan yang ingin diperoleh, biasanya berupa uang. Termasuk didalamnya bukan saja persetubuhan

86

${ }^{7}$ Moeljatno, 1994. Asas-Asas Hukum Pidana(Jakarta : Rineka Cipta). hlm

${ }^{8}$ Erdianto Effendi, 2011. Hukum Pidana Indonesia Suatu Pengantar Cet. 1.( Bandung : Refika Aditama) hlm 14

${ }^{9}$ W. A. Bonger, 1982. Pengantar tentang Krimonologi (Jakarta : Ghalia Indonesia) hlm 25 
tetapi juga setiap bentuk hubungan seksual dengan orang lain untuk mendapat bayaran. Di dalam Prostitusi terdapat beberapa pihak yakni pelacur (prostitute), mucikari atau germo (pimp) dan pelanggannya $(\text { client })^{10}$.

Prostitusi dalam pandangan masyarakat adalah termasuk kejahatan, karena memang akivitas prostitusi ini betul-betul sangat meresahkan masyarakat. Sehingga masyarakat sangat membenci prostitusi, walaupun KUHP tidak memberikan sanksi terhadap pelaku prostitusi, namun masrakat tetap menganggap sebagai suatu kejahatan yang sangat sulit untuk bisa diterima oleh masyarakat apapun alasannya. Sejalan asusmsi masyarakat terhadap kejahatan prostitusi ini. kejahatan bukan semata-mata merupakan batasan undang-undang, artinya ada perbuatan-perbuatan tertentu yang oleh masyarakat dipandang jahat, tetapi undang-undang tidak menyatakan sebagai kejahatan, (tidak dinyatakan sebagai tindak pidana) ${ }^{11}$.

Seorang sosiologi berpendapat (dalam jurnal legaliti, 81): menerangkan bahwa kejahatan itu bersumber di masyarakat yang memberi kesempatan untuk melakukan kejahatan dan masyarakat sendiri yang menanggung akibatnya dari kejahatan itu walaupun secara tidak langsung, oleh karena itu untuk mencari sebab-sebab kejahatan adalah dimasyarakat.

Pendapat tersebut menitik beratkan bahwa kejahatan bahwa penyebab dari tindak kejahatan/tindak pidana adalah karena masyarakat memberi kesempatan terhadap sejumlah kejahatan. Sehingga kejahatan tersebut tidak saja menjustifikasi pelakunya seperti para pelaku prostitusi tetapi juga pada masyarakat yang memeberikan kontribus i kepada mereka yang melakukan prostitusi.

\section{Prostitusi Dari Aspek Agama Islam}

Prostitusi/Pelacuran dalam pandangan Agama Islam disebut dengan zina yang dapat di artikan sebagai perbuatan persetubuhan atau bersenggama antara laki-laki dan perempuan yang tidak terikat oleh perkawinan yang syah. Zina itu sendiri dalam pandangan agama islam termasuk perbuatan dosa besar. Oleh karena itu, Islam telah memperingatkan agar manusia tidak terperangkap perzinaan sebagaimana juga diperingatkan dalam dalam al-Qur'an AlIsro: 32 sebagai berikut:

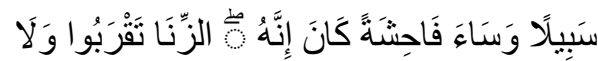

Artinya: “dan janganlah kamu mendekati zina; Sesungguhnya zina itu adalah suatu perbuatan yang keji. dan suatu jalan yang buruk."

\footnotetext{
${ }^{10}$ James A. Inciardi, $1997 \mathrm{hlm} 134$

${ }^{11}$ I. S. Susanto 2011, Pokok-pokok Hukum Pidana, Peraturan Umum dan Delik-Delik Khusus. Hlm 25
} 
Dalam Qur'an Surah An-Nur: 30:

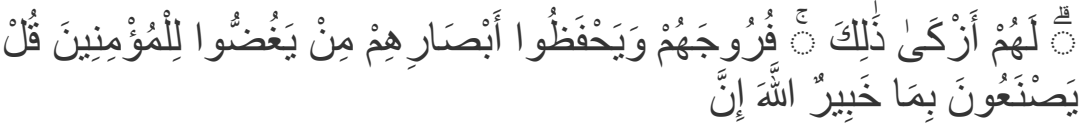

Artinya: Katakanlah kepada orang laki-laki yang beriman: "Hendaklah mereka menahan pandanganya, dan memelihara kemaluannya; yang demikian itu adalah lebih suci bagi mereka, Sesungguhnya Allah Maha mengetahui apa yang mereka perbuat".

Selanjutnya Allah berfirman dalam Al Qur'an An-Nur:

4-9

Artinya: "dan orang-orang yang menuduh wanita-wanita yang baik-baik (berbuat zina) dan mereka tidak mendatangkan empat orang saksi, Maka deralah mereka (yang menuduh itu) delapan puluh kali dera, dan janganlah kamu terima kesaksian mereka buat selama-lamanya. dan mereka Itulah orang-orang yang fasik."

Imam Al-Qurthubi (dalam Kitab Ahkamul Qu'an: 200) mengomentari bahwa Ayat ini menunjukkan bahwa tidak ada dosa yang lebih besar setelah kufur selain membunuh tanpa alasan yang dibenarkan dan zina". Dan menurut Imam Ahmad (Tafsir Kalaam AlMannan: 275) perbuatan dosa besar setelah membunuh adalah zina. Islam melarang dengan tegas perbuatan zina karena perbuatan tersebut adalah kotor dan keji. Allah berfirman: "Dan janganlah kamu mendekati perbuatan zina. Sesungguhnya zina itu suatu perbuatan yang keji dan suatu jalan yang buruk ${ }^{12}$

Syaikh Abdurrahman bin Nashir As-Sa'di, seorang ulama besar Arab Saudi (dalam Tafsir Kalaam Al- Mannan: 275) berkomentar: "Allah Swt telah mengategorikan zina sebagai perbuatan keji dan kotor. Artinya, zina dianggap keji menurut syara', akal dan fitrah karena merupakan pelanggaran terhadap hak Allah, hak istri, hak keluarganya atau suaminya, merusak kesucian pernikahan, mengacaukan garis keturunan, dan melanggar tatanan lainnya".

Oleh karena itu, Islam telah menetapkan hukuman yang tegas bagi pelaku zina dengan hukuman cambuk seratus kali bagi yang belum nikah dan hukuman rajam sampai mati bagi orang yang menikah. Di samping hukuman fisik tersebut, hukuman moral atau sosial juga diberikan bagi mereka yaitu berupa diumumkannya aibnya, diasingkan (taghrib), tidak boleh dinikahi dan ditolak persaksiannya. Hukuman ini sebenarnya lebih bersifat preventif (pencegahan) dan pelajaran berharga bagi orang lain. Hal ini mengingat dampak zina yang sangat berbahaya bagi kehidupan manusia, baik dalam konteks tatanan kehidupan individu, keluarga (nasab) maupun masyarakat.

${ }^{12}$ (Q.S. Al- Isra: 32). 


\section{Praktek Prostitusi di Kota Bima}

Kota Bima memiliki penduduk yang sangat heterogen tentu saja akan memiliki karakter dan dinamika kehidupan sosial yang sangat beragam. Keheterogenan ini tentu saja membawa konsekuensikonsekuensi logis terhadap kehidupan masyarakat Kota Bima secara universal dalam berbagai kehidupan masyarakat, yang akan menimbulkan akibat dari perubahan sosial dari segala aspek, salah satunya adalah aspek sosial. Persoalan perubahan sosial begitu cepat seiring dengan perkembangan kota seharusnya mendapat perhatian pemerintah Kota Bima dan masyarakat untuk menjawab berbagai problematika sosial, terutama masalah penyakit sosial seperti praktik prositusi terselubung yang dilakukan oleh kalangan pelajar dan mahasiswa sebagai insan akademis yang berpendidikan.

Saat ini praktek prostitusi terselubung pelajar dan mahasiswa di Kota Bima cukup mengkhawatirkan semua pihak. Praktek prostitusi terselubung ini berdampak pada aspek kehidupan masyarakat Kota Bima yang menjunjung tinggi nilai-nilai agama, berakibat pada terjadinya pergeseran nilai-nilai dalam kehidupan bermasyarakat, akibatnya prostitusi sebagai penyakit masyarakat yang bersifat universal harus dicarikan win-win solution, yang lebih fokus pada pelajar dan mahasiswa yang memiliki masa depan yang cerah, karena pelajar dan mahasiswa memiliki potensi, kapasitas, kapabilitas ilmu yang mumpuni jika dibandingkan dengan rakyat yang sama sekali tidak memiliki ilmu pengetahuan.

Maraknya praktek prostitusi tersebut di Kota Bima menjadi sebuah ancaman bagi masyarakat yang religius. Perilaku seks terselubung yang dilakukan oleh kalangan pelajar dan mahasiswa merupakan salah satu kegiatan yang memberikan dampak negatif bagi kehidupan masyarakat dan masa depan gerasi muda berikutnya, dimana saat ini kegiatan seks oleh pelajar dan mahasiswa sudah menjadi masalah yang sangat serius di Kota Bima, perbuatan tersebut dirasakan sebagai suatu perbuatan menyimpang karena sangat bertentangan dengan norma agama, norma kesopanan maupun norma kesusilaan sebagai nilai yang hidup dan berkembang serta dijunjung tinggi oleh masyarakat secara luas.

\section{Faktor Penyebab Pelajar dan Mahasiswa melakukan Praktik Prositusi Terselubung}

Hasil penelitian penulis menunjukan bahwa faktor yang melatar belakangi pelajar dan mahasiswa praktik prostitusi terselubung di Kota Bima dapat dibagi menjadi 2 (dua) faktor, yaitu faktor internal dan faktor eksternal. kedua faktor tersebut dapat dijelaskan sebagai berikut:

\section{Faktor internal}


Faktor Internal disini adalah faktor dalam diri si pelaku yang mempengaruhi dirinya sehingga terdorong melakukan praktik prostitusi terselubung, yaitu:

a. Rendahnya standar moral dan lemahnya iman dalam diri pelaku.

Pada aspek ini rata-rata mereka yang melakukan prostitusi terselubung semuanya beragama dan menyadari bahwa prostitusi di anggap sebagai perilaku yang dilarang oleh agama. Melalui pendidikan di ajarkan tentang adat atau cara hidup berdasarkan nilai-nilai moral dan agama yang di anutnya, akan tetapi tidak pernah dihayati dan di amalkan dalam kehidupan sehari-hari. Hal ini disebabkan oleh lemahnya rasa iman yang dimilki sehingga tak bisa menahan diri dari berbagai pengaruh yang mendorongnya untuk melakukan perbuatan tersebut.

Berkaitan dengan persolan moral dan iman ini, penulis telah melakukan wawancara terhadap 15 (lima belas) orang pelajar dan mahasiswa yang melakukan prostitusi terlubung di Kota Bima dengan pertanyaan yang sama sebagai berikut:

\begin{tabular}{|l|l|l|}
\hline No & \multicolumn{1}{|c|}{ Jenis Pertanyaan } & Jawaban \\
\hline 1. & Apakah anda beragama & Iya \\
\hline 2. & $\begin{array}{l}\text { Apakah di sekolah anda di ajarkan mengenai } \\
\text { moral, ahlak, dan iman }\end{array}$ & Iya \\
\hline 3. & $\begin{array}{l}\text { Apakah prostitusi diperbolehkan menurut } \\
\text { pengetahuan anda dalam agama }\end{array}$ & Tidak \\
\hline 4. & Apakah anda sering beribadah/ sholat & Tidak \\
\hline
\end{tabular}

Dari pertanyaan yang di ajukan tersebut di atas, semunya menjawabnya dengan sama yakni mereka beragama dan ratarata mengetahui jika perbuatan tersebut bertentangan dengan ajaran agama, dengan demikian dapat disimpulkan bahwa standar moral dan imannya memang lemah sehinga mereka dengan sangat mudah terpengaruh untuk melakukan prostitusi terselubung. Moral dan iman ini tentunya dapat kokok/kuat kalau sendainya mereka sering melaksanakan ibadah sholat, karena dengan demikian akan terhindar dari pengaruh dan perbuatan maksiat tersebut. Hal ini sebagaimana Allah SWT telah jelaskan dalam Q.S. Al-An-Am ayat 47 yang artinya" Dirikanlah Sholat, sesungguhnya sholat dapat menjegah keji dan mungkar".

b. Gaya hidup (life style).

Persolan gaya hidup (life style) menjadi faktor dominan yang mempengaruhi para pelajar dan mahasiswa dalam melakukan prostitusi terlubung, Kecenderungan ingin hidup senang dan bermewah-mewah, namun kondisi ekonomi diri dan 
keluarganya tidak mendukung kebutuhan hidupnya selalu memaksa mereka melakukan praktik prostitusi.

Hal ini sejalan dengan pengakuan seorang mahasiswa semester III di salah satu PTS di Kota Bima ${ }^{13}$ yang menyatakan bahwa ia benar melakukan prostitusi terlubung, adapun faktor yang menyebakan ia terpaksa melakukan praktik prostitusi terselubung karena untuk menutupi kebutuhan biaya hidup yang cukup tinggi antara lain; biaya sewa kos/ kontrakan, makanan sehari-hari, belanja pakaian, dan sejenisnya sehingga terpaksa melakukan prostitusi terlubung.

Hal yang sama juga dikemukan oleh dua orang narasumber lain ${ }^{14}$ yang merupakan mahasiswa semester V (lima) di dalah satu PTS Kota Bima mengemukan bahwa mereka harus melakukan aktifitas prostitusi semata-mata untuk mendapatkan uang guna keperluan hidup atau untuk memenuhi kebutuhan hidupnya seperti biaya kos, beli handphone, bayar cicilan sepeda motor, belanja pakaian, alat kosmetik, dan lain-lain.

Hasil penelitian penulis menunjukan bahwa hampir semua respondent yang telah diwawancara mengungkapkan alasan untuk memenuhi kebutuhan biaya hidup menjadi hal utama yang mendorong mereka melakukan prostitusi terselubung, meskipun ada beberapa orang yang mengungkapkan alasan lain. Jika dicermati aktifitas prostitusi terselubung ini dipandang mudah dilakukan dengan mendapatkan imbalan yang dirasakan cukup untuk memenuhi kebutuhan hidup rata-rata pelajar dan mahasiswa di Kota Bima.

c. Rasa stres (shock).

Berkaitan dengan faktor ini, penulis menemukan bahwa rasa stes (shock) yang dialami oleh mereka (pelajar dan mahasiswa) dapat mendorong kegiatan prostitusi terselubung dikalangan mereka, rasa stres (shock) setidaknya dipengaruhi oleh 2 (dua) hal; yakni:

1. Karena masalah keluarga (orang tua)

Hubungan keluarga yang kurang harmonis, kadang memicu munculnya prostitusi terselubung bagi anak. Terkadang aktifitas kesibukan kedua orang tua sehingga sehingga kurang memberikan perhatian terhadap anak atau karena kehidupan orang tua yang kurang harmonis sehingga kedua orang tua tua pisah (bercerai) sehingga membuat anak tidak terusus dan terkontrol. Tempat tinggal yang jauh dari

\footnotetext{
13 Wawancara dilakukan pada 20 September 2016, Pukul: 18.45 Wita. Nama narasumber tidak dicantumkan untuk menjaga privasi yang bersangkutan

${ }^{14}$ Wawncara dilakukan pada 23 September 2016, Pukul: 22.45 Wita. Nama narasumber tidak dicantumkan untuk menjaga privasi yang bersangkutan
} 
orang tua memberi peluang dan kebebasan bagi anak untuk melakukan hal yang dikehendakinya sendiri termasuk prostitusi terselubung. ${ }^{15}$

2. Karena putus cinta

Faktor putus cinta menjadi pemicu bagi seorang perempuan stres sehingga nekat melakukan prostitusi terlubung. Menurut narasumber seorang siswa/pelajar yang masih duduk dibangku kelas 2 (dua) dan kelas 3 (tiga) pada salah satu SMA di Kota Bima, menguraikan secara gamblang tentang aktifitas prostitusinya, dari uraian ini penulis dapat simpulkan sebagai berikut. 16

a) Ia terpaksa melakukan praktik prostitusi terselubung karena ia shock mental ditinggal oleh pacarnya setelah keperawanannya didapat;

b) Karena desakan kebutuhan dan biaya hidup (belanja, sewa kos-kosan) yang serba mahal, sehingga terpaksa melakukan pekerjaan tersebut.

\section{Faktor eksternal}

Faktor Eksternal disini adalah faktor diluar diri pelaku yang mempengaruhi si pelaku sehingga terdorong melakukan praktik prositusi terselubung, yaitu:

a. Tidak adanya sanksi hukum yang jelas dan tegas;

Prostitusi atau Pelacuran bila dilihat dalam perspektif hukum positif utamanya dalam Kitab undang-undang Hukum Pidana (KUHP) maka dapat ditemukan bahwa tidak ada satu pasal pun yang mengatur secara tegas dan khusus mengenai prostitusi atau pelacuran, dengan demikian secara kriminologis sulit untuk mengatakan bahwa pelacuran itu sebagai suatu kejahatan atau tindak pidana, sebab tidak menimbulkan korban.

Oleh karena tidak adanya larangan dan ancaman pidana yang tegas dan jelas mengenai pelaku prostitusi atau pelacur prostitusi dalam dalam ketentuan KUHP, membawa konsekwensi bahwa palacuran apakah dia laki-laki atau perempuan bukanlah termasuk seorang penjahat dalam

${ }^{15}$ Berdasarkan wawancara dengan Narasumber seorang siswa/pelajar yang masih duduk dibangku kelas 2 (dua) pada salah satu Sekolah Menengah Atas (SMA) di Kota Bima (tanggal 3 Oktober 2016, Pukul: 16.45 Wita), ia menjelaskan disamping karena ekonomi (motif gaya hidup), ia pun terpaksa melakukan praktik prostitusi terselubung disebabkan ia mengalami stres dengan masalah orang tua yang tidal akur dan kini sudah cerai dan masing-masing sudah menikah lagi. Dalam kondisi ini, ia merasa sudah tidak ada lagi memperhatikan dan membiayai sekolahnya termasuk kebutuhan hidupnya, kondisi ini tentunya menjadi penyebab bagi dia untuk melaksanakan aktifitas prostitusi.

${ }^{16}$ Wawancara dilakukan pada tanggal, 3 Oktober 2016, Pukul: 20.15 Wita. Nama narasumber tidak dicantumkan untuk menjaga privasi yang bersangkutan 
kualifikasi yuridis, meskipun hal ini bertentangan dengan sosiologi dari kejahatan (Sociological Difinition of crime) yakni kejahatan atau perbuatan tidak saja yang diatur atau dilarang dalam norma hukum positif melainkan apa yang disebut dengan perbuatan jahat itu juga harus dilihat dari norma-norma sosial yang masih hidup dan berkembang dalam masyarakat. Tidak dicantumkannya secara tegas dan jelas mengenai perbuatan prositusi atau pelacuran dalam Kitab UndangUndang Hukum Pidana (KUHP) sebetulnya tidak saja berpengaruh terhadap sulitnya aparat penegak hukum terutama kepolisian dalam menegakan hukum dibidang prostitusi atau pelacuran ini melainkan juga berdampak pada hilangnya rasa takut bagi mereka yang akan melakukan aktiftas prostitusi atau pelacuran sehingga prostitusi pun makin merajalela.

b. Adanya dorongan atau pengaruh lingkungan (teman);

Dorongan untuk melakukan aktifitas prostitusi terselubung tidak semata-mata muncul karena keinginan dalam diri sendiri melainkan juga dapat dipengaruhi oleh teman/kerabat. Hal mana menurut pengakuan Fitri dan Putri (tanggal, 15 Oktober 2016, Pukul: 21.30 Wita) yang saat ini masih sebagai mahasiswa semester V (lima) pada salah satu PTS di Kota Bima mengungkapkan bahwa pada awal dia memulai praktik prostitusi bermula ketika ia diajak oleh salah seorang temannya yang kebetulan lebih dulu melakukan praktik yang demikian, menurutnya ia merasa tertarik melakukan praktik prositusi terselubung karena merasa ingin mengikuti gaya hidup temannya tersebut yang serba mewah.

c. Kurangnya kontrol orang tua, pemilik rumah kontrakan, maupun pemilik hotel.

Maraknya prostitusi dikalangan pelajar dan mahasiswa di Kota Bima juga tidak terlepas dari lemahnya peran orang tua, pemilik rumah kontrakan maupun pemilik hotel sehingga menyebabkan pelajar dan mahasiswa dapat secara bebas melakukan aktifitas prostitusi. Sebagaian besar pelaku prostitusi yang berhasil diwawancara oleh penulis rata-rata mereka hidup dengan menyewa rumah kos-kosan yang jauh dengan orang tua dan keluarga, bahkan rumah kos-kosan mereka pun jarang diketahui oleh orang tuanya. Hasil Identifikasi penulis ditemukan bahwa tempat yang sering digunakan oleh mereka dalam melakukan aktiftas prostitusi di antaranya;

1) Rumah kos/ kontrakan mereka sendiri; dan

2) Hotel atau penginapan.

Para pelajar dan mahasiswa yang sudah biasa menggeluti prostitusi terlubung sengaja memilih lingkungan 
rumah kos-kosan yang lokasinya steril atau jauh dari perkampungan warga maupun jauh dari pemiliknya. Kondisi rumah kos-kosan yang demikian membuat mereka leluasa membawa masuk tamunya (pelanggannya) diwaktu siang maupun malam karena tidak di awasi secara langsung oleh pemilik rumah kos-kosan, bahkan pemilik rumah kos-kosan pun sama sekali tidak mengetahui adanya aktifitas prostitusi di rumah kos-kosannya.

Demikian juga halnya dengan pemilik atau penjaga hotel atau penginapan, penulis tidak menemukan adanya aturan/ tata tertib yang ketat bagi pengujung yang ingin menyewa kamar hotel, misalnya adanya larangan membawa tamu lawan jenis (bukan suami/isteri) kedalam kamar hotel, dan sebagainya. Kondisi ini juga ikut memudahkan mereka yang melaksanakan aktifitas prostitusi.

d. Kurangnya pengawasan pemerintah

Aktifitas prostitusi dikalangan pelajar dan mahasiswa di Kota Bima selama ini memang jarang diketahui masyarakat luas utamanya pemerintah Kota Bima, karena prostitusi dikalangan pelajar dan mahasiswa tersebut memang dilakukan secara terselubung. Selama ini Pemerintah Kota Bima melalui Satuan Polisi Pamong Praja (Satpol PP) maupun Dinas Sosial baru menangani prostitusi ini terbatas pada pekerja prostitusi umum dan tidak mengetahui jika prostitusi tersebut sudah menyebar hingga kalangan pelajar dan mahasiswa. Muhammad Jafar, S. Sos Kabid Rehabitasi dan Bantuan Sosial Dinas Kota Bima ${ }^{17}$ mengatakan bahwa selama ini belum pernah menangani prostitusi di tingkat pelajar dan mahasiswa, adapun pekerja prostitusi yang pernah di binanya merupakan pekerja prostitusi umum, bukan dari kalangan pelajar dan mahasiswa. Bahkan menurutnya ia baru mengetahui adanya prostitusi di kalangan pelajar dan mahasiswa justru dari data yang disajikan oleh peneliti pada saat proses wawancara berlangsung.

Menurut penulis ketidaktahuan Pemerintah mengenai maraknya prostitusi di kalangan pelajar mengindikasikan 2 (dua) hal sebagai berikut:

1. Bahwa aktifitas prostitusi dikalangan pelajar dan mahasiswa ini betul-betul dilakukan secara rahasia dan hanya diketahui oleh orang-orang tertentu yang berhubungan langsung dengan mereka;

2. Pemerintah rupanya kurang begitu kontrol terhadap setiap fenomena kehidupan masyarakat yang dinamis, utamanya perilaku prostitusi dikalangan remaja.

\footnotetext{
${ }^{17}$ Wawancara 21 Oktober 2016 Pukul: 10.00 WITA
} 
Kondisi ini menggambarkan betapa Pemerintah kota bima belum memberikan perhatian khusus terkait fenomena prostusi di Kota Bima seolah-olah perbuatan semacam ini tidak begitu membahayakan kelangsungan hidup masyarakat, padahal perilaku prostitusi sendiri sangat ditentang oleh masyarakat. Selama ini Pemerintah Kota Bima baru fokus pada masalah pengemis, anak jalanan, pedagang kaki lima, perjudian, minuman keras melalui Peraturan Daerah Nomor 7 Tahun 2015 tentang Ketertiban umum, atau baru mengatur tentang perlindungan anak melalui peraturan daerah Nomor 1 tahun 2016. Belum ada Peraturan Daerah tentang Larangan Maksiat atau Larangan Prostitusi. Padahal dampak dari prostitusi ini cukup luas dan cukup meresahkan masyarakat, hal ini diperlukan keterlibatan pemerintah secara aktif untuk ikut mengawasai aktifitas prostitusi guna menciptakan kehidupan aman, nyaman dan tentram dikalangan masyarakat.

Dari uraian di atas menunjukan bahwa tidak ada faktor tunggal yang mempengaruhi pelajar dan mahasiswa melakukan prostitusi melainkan dipengaruhi oleh banyak faktor utamanya tuntutan gaya hidup (life style). Untuk lebih jelasnya gambaran mengenai faktor yang menyebabkan prostitusi terselubung di kalangan pelajar dan mahasiswa di Kota Bima dapat dijelaskan dalam bentuk bagan/ skema berikut ini:

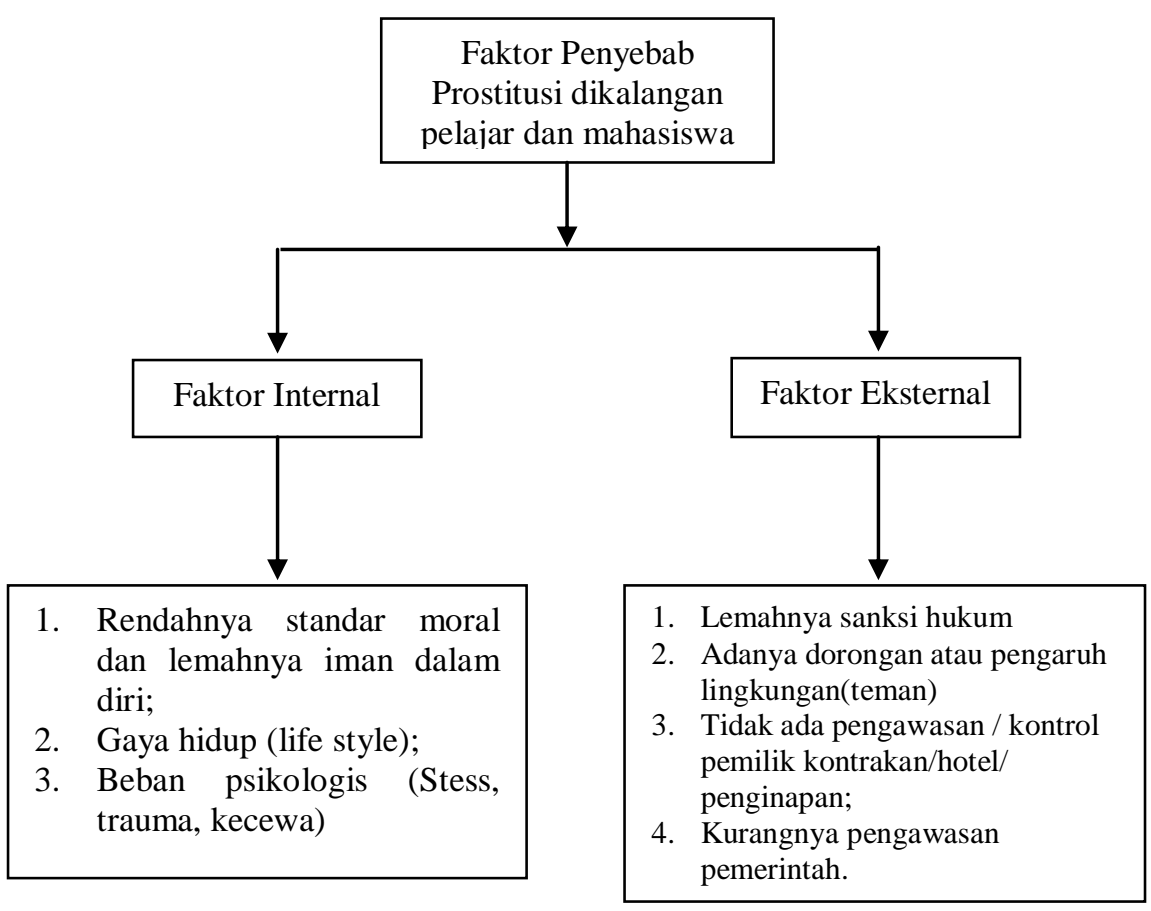




\section{Peran masyarakat dan Pemerintah Kota Bima dalam menanggulangi Praktik Prostitusi terselubung di Kota Bima;}

Kejahatan prostitusi ini mempunyai dampak negatif yang begitu besar bagi kelangsungan hidup bermasyarakat, maka perlu dicegah agar tidak meningkat bahkan jika bisa agar dihilangkan sama sekali ditengah kehidupan masyarakat. Untuk menanggulagi hal tersebut tentunya tidak cukup dengan mengandalkan sarana hukum, melainkan juga diperlukan peran serta masyarakat dan pemerintah agar praktik prostitusi dikalangan pelajar dan mahasiswa tidak semakin berkembang.

\section{Peran Serta Masyarakat Kota Bima}

Seorang ahli sosiologi berpendapat dari sudut sosiologis Bahwa kejahatan itu bersumber di masyarakat, masyarakat yang memberi kesempatan untuk melakukan kejahatan dan masyarakat sendiri yang menanggung akibatnya dari kejahatan itu walaupun secara tidak langsung, oleh karena itu untuk mencari sebab-sebab kejahatan adalah di masyarakat (F.X. Rudy Gunawan, 2003: 19) Pendapat tersebut di atas menitik beratkan bahwa penyebab terjadinya kejahatan/tindak pidana adalah karena masyarakat memberi kesempatan terhadap timbulnya kejahatan sendiri.

Peran serta masyarakat dalam menanggulangi kejahatan prostitusi di kalangan pelajar dan mahasiswa ini sangat penting dilakukan melibatkan segenap komponen yang berperan sebagai berikut:

a. Peran Orang Tua atau keluarga

Bagaimanapun juga peranan orang sangat penting dalam membimbing anak, terutama ikut membantu anak dalam berbagai masalah yang dihadapinya utamanya dalam mengatasi tekanan dan pengaruh negatif dari lingkungan dan teman sekitarnya. Orang tentunya harus bisa kontrol serta mengawasi setiap aktiftas yang dilakukan oleh anaknya sebagai bentuk perhatian dan kewaspadaan terhadap anak agar terhindar dari perilaku-perilaku menyimpang seperti seks bebas dan sebagainya, upaya kontrol tidak berarti mengekang, tetapi bersikap peduli dan perhatian terhadap hal-hal yang dilakukannya.

Adapun peranan orang tua atau keluarga guna menghindari anaknya terlibat dalam prostitusi yakni menumbuhkan kesadaran dan pengetahuan anak tentang hal sebagai berikut:

- Menanamkan pendidikan agama, moral, dan akhlak pada setiap anak sejak usia dini;

- Membiasakan anak hidup hemat dan sederhana; 
- Menjauhkan anak-anak dari pengaruh budaya barat yang berusaha mempengaruhinya;

- Memberikan pengetahuan tentang bahaya prostitusi, narkoba, dan pergaulan bebas;

- Membangun komunikasi yang intens dengan anak.

- Memberikan perhatian dan kasih sayang penuh terhadap anak;

- Berusaha menyelesaikan setiap kesulitan dan masalahmasalah yang dihadapi oleh anak;

- Berusaha memenuhi dan mencukupi kebutuhan anak.

b. Peran Pemilik rumah kontrakan, hotel dan penginapan.

Selama ini prostitusi di kalangan pelajar dan mahasiswa marak terjadi juga turut disebabkan oleh lemahnya pengawasan dari pihak pemilik rumah maupun pemilik hotel dan penginapan. Data yang ditemukan penulis bahwa prostitusi sering dilakukan di rumah kos-kosan, hotel, dan penginapan, hal ini terjadi karena kurangnya pengawasan dari pemiliknya. Demikian juga halnya dengan para pemilik hotel dan penginapan agar membuat peraturan dan tata-tertib guna mencegah terjadinya prostitusi.

Upaya sederhana dapat dilakukan secara seksama dengan penuh kesungguhan baik dari pemilik kos-kosan atau kontrakan maupun oleh pemilik hotel dan penginapan, meskipun tidak mampu menghilangkan sama sekali namun dapat meminimalisir tingkat prostitusi terutama yang dilakukan oleh kalangan pelajar dan mahasiswa di Kota Bima.

c. Peran Tokoh Pemuda dan Tokoh Masyarakat.

Peran tokoh pemuda dan tokoh masyarakat sangat diperlukan guna menanggulangi kejahatan prostitusi dikalangan pelajar dan mahasiswa, upaya yang dapat dilakukan antara lain dengan ikut mengawasi dan mengontrol bersama segala aktifitas di lingkungan tempat tinggal pelajar dan mahasiswa yang tinggal menggunakan rumah kos-kosan atau rumah kontrak, selama ini masyarakat disekitar kadang apatis dengan aktifitas kehidupan pelajar dan mahasiswa disekitarnya. Sikap apatis ini ditunjukan dengan masa bodoh, seolah-olah tidak ingin mau tahu aktifitas kehidupan pelajar dan mahasiswa yang tinggal disekitarnya.

Kedepan masyarakat tidak boleh lagi bersikap apatis atau memberikan ruang bagi terciptanya perilaku prostitusi di kalangan pelajar dan mahasiswa, melainkan secara bersamasama harus mengambil peran untuk mengantisipasi maraknya prostitusi ini, karena bagaimanapun juga prostitusi tidak saja berdampak buruk bagi mereka yang melakukannya melainkan 
juga ikut memberikan dampak buruk pada lingkungan sekitar maupun masyarakat pada umumnya.

\section{Peran serta Pemerintah Kota Bima.}

Mengingat prostitusi di kalangan pelajar dan mahasiswa di Kota Bima selama sudah cukup banyak terjadi bahkan jika dibiarkan dapat memberikan akses negatif bagi kehidupan masyarakat luas, maka usaha penanggulangannya tidak cukup hanya dilakukan oleh Orang Tua, Pemilik Rumah Kontrakan atau kontrakan, atau masyarakat saja, melainkan juga diharapkan adanya keterlibatan Pemerintah Kota Bima secara aktif guna mengantisipasi dan menanggulangi masalah prostitusi yang marak terjadi selama ini.

Secara garis besar usaha untuk menanggulangi atau meminimalisir kejahatan prostitusi di Kota Bima dapat dilakukan melalui 2 (dua) upaya yaitu:

a. Upaya preventif (pencegahan),

Sebagai upaya pencegahannya, Pemerintah Kota Bima dapat melakukan langkah-langkah sebagai berikut:

1) Menyusun peraturan perundang-undangan (peraturan daerah) yang tegas dan jelas mengenai larangan praktik prostitusi di Kota Bima;

2) Membuat peraturan daerah tentang penataan rumah kontrakan/kos-kosan yang memisahkan kontrakan/koskosan antara laki-laki dan perempuan;

3) Intensifikasi pemberian pendidikan keagamaan, moral dan ahlak guna memperkuat keimanan dan ketakwaan pada pelajar dan mahasiswa;

4) Menciptakan bermacam-macam kesibukan dan kesempatan rekreasi bagi anak-anank puber dan adolesens untuk menyalurkan kelebihan energinya;

5) Menyelenggarakan pendidikan bahaya seks dan dan meningkatkan pemahaman terhadap nilai perkawinan dalam kehidupan keluarga;

6) Membentuk badan atau tim koordinasi dari semua usaha penanggulangan prostitusi yang dilakukan oleh beberapa instansi sekaligus mengikutsertakan potensi masyarakat lokal untuk membantu melaksanakan kegiatan pencegahan atau penyebaran prostitusi;

7) Memblokir situs-situs porno dan melakukan penyitaan terhadap buku-buku dan majalah-majalah bermuatan cabul, gambar-gambar porno, dan sarana-sarana lain yang merangsang nafsu seks;

8) Menciptakan lapangan kerja baru guna meningkat kesejahteraan masyarakat pada umumnya. 
b. Upaya atau tindakan represif dan kuratif.

Upaya atau tindakan represif dan kuratif sebagai bentuk upaya untuk menekan (menghapus, menindas) secara tegas pelaku atau mereka yang terlibat dalam kegiatan prostitusi serta usaha untuk menyembuhkan atau memulihkan para pelajar dan mahasiswa yang sudah nyata terindikasi melakukan prostitusi agar kedepan aktifitas semacam ini dapat ditinggalkan sama sekali.

Hemat penulis, usaha-usaha seperti ini antara lain meliputi:

1) Melakukan rajia rutin pada sejumlah tempat (rumah koskosan, hotel atau penginapan) yang diduga menjadi tempat prostitusi terselubung selama ini;

2) Menyediakan sanksi hukum yang tegas bagi pelaku prostitusi (laki dan perempuan), bahkan bagi setiap orang yang secara sengaja membiarkan dan/atau memberikan kemudahan bagi aktiftas prostitusi;

3) Melakukan rehabilitasi dan resosialisasi terhadap pelajar dan mahasiswa yang teridenfikasi terlibat prostitusi agar mereka dapat tumbuh dan berkembang sebagai manusia yang bermoral dan bertabat;

\section{Simpulan}

Dari hasil penelitian yang telah dibahas di atas, maka dapat ditarik suatu kesimpulan sebagai berikut:

1. Bahwa faktor yang menyebabkan pelajar dan mahasiswa melakukan prostitusi terselubung di Kota Bima disebabkan oleh 2 (dua) faktor yakni faktor internal dan faktor eksternal. Faktor internal dimaksud merupakan faktor yang terdapat dalam diri pelaku antara lain; rendahnya standar moral dan lemahnya kualitas iman, gaya hidup (life style) yang berlebihan, beban psikologis (trauma, kecewa, dll), sedangkan faktor eksternal yakni faktor yang berada diluar diri pelaku yakni lemahnya sanksi hukum, pengaruh lingkungan (teman), kurangnya pengawasan baik orang tua, masyarakat, maupun pemerintah sehingga ikut mendorong terjadinya prostitusi terselubung dikalangan pelajar dan mahasiswa. Lebih lanjut dapat dikemukakan ternyata faktor dominan yang mempengaruhi mereka melakukan prostitusi karena tuntutan gaya hidup (life style) yang serba mewah dan mahal, sementara kondisi ekonomi keluarga tidak mampu menutupi berbagai kebutuhan mereka sehingga membuat mereka terpaksa melakukan prostitusi terselubung.

2. Guna menanggulangi maraknya prostitusi terselubung dikalangan pelajar dan mahasiswa tersebut, tentunya tidak cukup dengan mengandalkan pengawasan yang melekat dari masing-masing 
orang tua dan keluarga namun juga diperlukan peran serta masyarakat dan pemerintah Kota Bima. Terutama para pemilik rumah kos-kosan atau kontrakan, pemilik hotel atau penginapan yang selama ini seringkali digunakan sebagai tempat prostitusi terselubung dengan cara membuat tata tertib atau aturan bagi setiap penghuni rumah kos-kosan atau kontrakan, penyewa atau pengunjung hotel atau penginapan dengan melarang membawa masuk tamu yang bukan muhrimnya kedalam kamar.

Selain itu, tokoh masyarakat dan pemuda juga harus ikut memperhatikan segala aktifitas pelajar dan mahasiswa yang menempati rumah kos-kosan atau rumah kontrakan, hal ini dilakukan guna memastikan bahwa lingkungan kos-kosan atau rumah kontrakan yang ditempati oleh mereka tidak digunakan sebagai tempat prostitusi. Sedangkan Pemerintah Kota Bima dapat melakukan upaya, utamanya tindakan preventif (pencegahan) dengan membuat peraturan daerah tentang larangan prostitusi atau larangan maksiat, memberikan pendidikan bahaya seks bebas pelajar dan mahasiswa, membuka lapangan kerja guna meningkatkan kesejahteraan rakyat, dan sebagainya. disamping itu juga diharapkan adanya tindakan represif dari pemerintah kota bima dengan cara menentukan sanksi yang tegas bagi pelaku maupun pihak-pihak yang turut serta menyediakan dan/atau memudahkan kegiatan prostitusi, melakukan rajia rutin terhadap sejumlah rumah kos-kontrakan maupun hotel atau penginapan yang dicurigai sebagai tempat prostitusi, dan sebagai upaya terakhir juga diharapkan ada upaya rehabilitasi dan resosialisasi terhadap mereka yang teridentifikasi sebagai pelaku prostitusi agar mereka dapat tumbuh dan berkembang sebagai manusia yang bermoral dan bertabat kedepannya.

\section{Daftar Pustaka}

Alam, A.S. 1984. Pelacuran dan Pemerasan, penerbit Alumni, Badung.

Anwar, Mochamad Dading, 1986. Hukum Pidana bagian Khusus Buku II, Alumni Bandung.

A. Ridwan Halim, 1986. Hukum Pidana dalam Tanya Jawab Cet. 4, Ghalia Indonesia, Jakarta.

Bambang Waluyo, 1986. Penelitian Hukum Dalam Praktek, Sinar Grafika, Jakarta, 1996.

Erdianto Effendi, 2011. Hukum Pidana Indonesia Suatu Pengantar Cet. 1, Refika Aditama, Bandung.

Moelyatno, 1993. Asas-Asas Hukum Pidana, Rineka Cipta, Jakarta. 
P.A.F. Lamintang, 2011. Dasar-Dasar Hukum Pidana Indonesia, Cet. 4, Citra Aditya Bakti, Bandung.

R. Soesilo, 1974. Pokok-pokok Hukum Pidana, Peraturan Umum dan DelikDelik Khusus, Cet. 1, Politea, Bogor. 1995, Kitab Undang-Undang Hukum Pidana, Polite Bogor.

S.R. Sianturi, 1996. Asas-Asas Hukum Pidana di Indonesia dan Penerapannya, Alumni Ahaem-Petehaem, Jakarta.

Soerjono Soekanto, 1986. Pengantar Penelitian Hukum, UI Press, Jakarta.

Soenaryo, 1985. Metode Riset I, Universitas Sebelas Maret, Surakarta.

Sudarto, 1983. Hukum dan Hukum Pidana, Alumni, Bandung.

Sudjono D, 1988. Pathologi Sosaial, Peneribit alumin, bandung.

Wijono Prodjodikoro, 2008. Tindak-Tindak Pidana Tertentu di Indonesia, Cet. 2, Refika Aditama, Bandung.

Yan Pramadya Puspa, 1977. Kamus Hukum Lengkap Bahasa Belanda, Indonesia, Inggris, Aneka Ilmu, Semarang.

Kartini kartono, Patologi Sosial Jilod I, Edisi Baru, CV Rajawali Jakarta, 1988

----------, 2005, Patologi Sosial Jilid I, Edisi Revisi, CV Rajawali Jakarta,

Cahyo Purnomo, Ashadi Siregar, 1994. Membedah Pelacuran Kasus Kompleks Pelacuran Doly, Grafiti pres, Yogyakarta.

W.A. Bonger, 1982. Pengantar tentang Krimonologi, Ghalia Indonesia, Jakarta.

Niken Savitri, 2008. HAM Perempuan, Kritik Teori Hukum Femin Terhadap KUHP, Rafika Aditama, Jakarta.

Tongat, 2003. Hukum Pidana Materiil, Tindak Pidana Terhadap Subyek Hukum, Jambatan, Jakarta.

Amir Ilyas, 2012. Asas-asas Hukum pidana, Rangkang Education \& PuKAP-Indonesia, Yogyakarta.

Andi Hamzah, 1994. Asas-Asas Hukum Pidana, Reineka Cipta, Jakarta.

Hull.T. Sulistyaningsih, E dan Jones, 1999. Pelacuran di Indonesia, Sejarah dan Perkembangannya, Pustaka Sinar Harapan, Jakarta.

A.Supratik. 1995. Tinjauan Psikologi Komunikasi Antar Pribadi. Kanisius (Anggota IKAPI). Yogyakarta.

F.X. Rudy Gunawan, 2003. Mengebor Kemunafikan: Inul, Sex dan Kekuasaan, Kawan Pustaka, Jogyakarta.

Peraturan Perundang-Undangan

Undang-Undang Dasar (UUD) NRI 1945

Kitab Undang-Undang Hukum Pidana (KUHP) 